\title{
A NOTE ON CHARITABLE GIVING BY CORPORATES AND ARISTOCRATS: EVIDENCE FROM A FIELD EXPERIMENT*
}

\author{
VITTORIO BASSI ${ }^{\dagger} \quad$ STEFFEN HUCK $^{\ddagger} \quad$ IMRAN RASUL $^{\S}$ \\ UNIVERSITY COLLEGE LONDON
}

APRIL 2016

\begin{abstract}
Multiple sources of funding are becoming increasingly important for charitable organizations. Donations from corporate donors for example account for $25-35 \%$ of charitable income for the largest US charities, across charitable sectors. This note presents some tentative first evidence from a natural field experiment to shed light on how different types of potential donors: individuals, corporates and aristocratically titled individuals, respond to the same fundraising drive. Each donor type was randomly assigned to treatments varying in two dimensions: (i) whether information was conveyed about the existence of an anonymous lead donor; (ii) how individual donations would be matched by the anonymous lead donor. We find that aristocrats are significantly more likely to respond and that corporates give significantly more than individuals. Treatment effects moreover suggest that (proportional) matching is to be avoided for corporate donors.

Keywords: agency problems; charitable giving; corporate donors; aristocratic donors; field experiment.

JEL Classification: C93, D12, D64.
\end{abstract}

${ }^{*}$ We gratefully acknowledge financial support from the ESRC and ELSE. We thank all those at the Munich Opera House, Actori, and Maurice Lausberg for making this project possible. This paper has been screened to ensure no confidential information is revealed. All errors remain our own.

${ }^{\dagger}$ Department of Economics University College London, Drayton House, 30 Gordon Street, London WC1E 6BT, United Kingdom. E-mail: vittorio.bassi.09@ucl.ac.uk

${ }^{\ddagger}$ Department of Economics and the ESRC Centre for Economic Learning and Social Evolution, University College London, Drayton House, 30 Gordon Street, London WC1E 6BT, United Kingdom. E-mail: s.huck@ucl.ac.uk.

$\S$ Department of Economics and the ESRC Centre for Economic Learning and Social Evolution, University College London, Drayton House, 30 Gordon Street, London WC1E 6BT, United Kingdom. E-mail: i.rasul@ucl.ac.uk. 


\section{Introduction}

Many social commentators today suggest that a second great age of philanthropy is upon us. Some of the world's wealthiest individuals, such as Bill Gates and George Soros, contribute vast sums to good causes, mimicking the philanthropic behavior of the Carnegies, Mellons and Rockefellers of the nineteenth century. Such trends are of course not confined to America-for example the Scottish entrepreneur Sir Tom Hunter announced in 2007 his intention to redirect over $£ 1$ bn of his personal fortune into charitable projects worldwide. At the same time, similar initiatives towards good causes are now well established among corporate donors. Two well known charitable drives led by corporates are the Livestrong and Red campaigns. The Livestrong campaign, a partnership between Nike and the Lance Armstrong Foundation and Endowment, raised over $\$ 50$ million in 2009 , with $\$ 5$ million coming from merchandise sales including the famous yellow wristbands. Since its inception in 2006, Product Red campaign has raised over $\$ 150$ million for the Global Fund to help eliminate AIDS in Africa through events and the sale of Red products by corporations such as Gap and Apple.

Despite vast sums being given by philanthropic and corporate donors, the bulk of the economics literature on charitable giving has focused on the determinants of why and how individuals give. ${ }^{1}$ Far less attention has been given to the charitable behavior of other donor types, such as corporates or aristocrats - namely those with some formal title such as Earl or Baron and who might therefore be from a family dynasty with a history of philanthropy. This paper presents evidence from a large-scale natural field experiment designed to shed light on how corporates, aristocrats, and individuals, differ in their response to the same fundraising scheme. We provide some first tentative evidence to help understand whether and how each recipient type responds to commonly used methods in fundraising, such as the presence of lead donors and donations being matched at some rate. In doing so, we address new questions of how charitable organizations might design and target fundraising activities to harness funds from corporate and aristocratic donors.

Information about aggregate donations from aristocrats is scarce. However, to motivate our analysis and to get a wider sense of the importance of corporate giving, we collected evidence from Forbes' 'America's 200 Largest Charities' list, as ranked by the value of private donations to them, published in 2005. The most recent publicly available balance sheets were examined for 199 of the 200 charities included in the list. ${ }^{2}$ It was possible to collect detailed information on the sources of funds for 20 of these 199 charities. In particular, the financial statements of these 20 charities allow us to break down sources of funding into the following types: (i) government/not-for-profit organizations; (ii) corporations; (iii) individuals. To understand whether funding sources differ by

\footnotetext{
${ }^{1}$ In a recent special issue on charitable giving in the Journal of Public Economics, nearly all the papers focussed on the determinants of why individuals give. Andreoni [2006] discusses the few papers that have studied giving by the very wealthy.

${ }^{2}$ The charity 'World Opportunitites' was excluded from the analysis as information on this charity is not accessible online.
} 
the nature of work conducted by the charitable organization, we classify charities as operating in one of the following sectors: (i) humanitarian relief; (ii) medical; (iii) environment; (iv) arts and culture; (v) education. ${ }^{3}$

Table 1 summarizes the data on funding sources by charitable organization type. All three sources of funding: government, corporate and individual, are important across charitable sectors. In line with the evidence presented by Andreoni [2006], we see that on average, $30 \%$ of all donations across charitable sectors originate from corporates. The last row shows that government and individual donations represent $25 \%$ and $34 \%$ respectively of all donations. In arts and culture (the charitable sector most relevant to the field experiment discussed below), corporate donations correspond to $20 \%$ of all donations, a higher percentage than in other charitable sectors such as the environment or education. As Column 6 makes clear, corporate donations are more significant relative to individual donations for charities in the medical and education sectors. While any figures based on this selected sample of charities is of course subject to many caveats, they nonetheless suggest the importance of studying giving behavior of donors other than individuals, that have been the focus of much of the literature on philanthropy in economics. It is in this direction that our paper contributes by providing some tentative new evidence from a natural field experiment.

More precisely, in conjunction with the Bavarian State Opera in Munich, in June 2006, we mailed 25,000 recipients - including corporates, aristocrats, and regular opera attendees (whom we label 'individuals') — a letter describing a charitable fundraising project organized by the opera house. All recipient types in our study are recorded to have previously purchased tickets from the opera house. Corporates might have purchased tickets for employees or clients. The aristocrats in our study are all recorded in the opera's database as having a formal title of some sort, such as Baron, Baroness, Earl and so forth. In the German context, such aristocratic families are likely to have a long philanthropic association with the arts. ${ }^{4}$

Recipients were randomly assigned to mail out treatments that varied in two dimensions: (i) whether information was conveyed about the existence of an anonymous lead donor; (ii) how individual donations would be matched by the anonymous lead donor. The field experiment sheds light on how each recipient type responds to the presence of lead donors and the relative price of giving. We do so for both the extensive margin of giving (whether any positive donation is made) and the intensive margin (how much is donated conditional on a donation being made). The behavioral response of individual donors to the field experiment is analyzed in more detail in Huck and Rasul [2011], where we document how sensitive individuals are to the presence of a

\footnotetext{
${ }^{3}$ The following assumptions were made regarding donation sources: (i) donations under the heading 'legacies' or 'bequests' are assumed to come from individuals; (ii) donations falling under the heading 'gifts in-kind' or 'donated services' are equally split between individuals and corporations, unless it is clearly stated in the financial statements what their origin is. The classification of charities into sector is based on the core activities performed.

${ }^{4}$ The titled donors do not include Doctoral or Professorial titles. Of course there might be some individuals with such titles that choose not to use them and they would be mis-classified as individuals in our study, although this type of measurement error is not expected to be first order and would of course make it harder to detect statistical differences in the behavior of individuals and aristocrats.
} 
lead donor and calculate price elasticities of response and in Huck et al. [2015] where we estimate a structural model of individual giving. Here the main emphasis is on the behavior of the smaller sample of corporate and aristocratic donors.

We add to two strands of literature, one long-standing and one emerging. We first contribute to the vast literature on the determinants of charitable giving. The bulk of this literature has studied why individuals give, estimating individual price and income elasticities of giving [Randolph 1995, Auten et al. 2002, Huck and Rasul 2011], understanding the non-price determinants of giving [Karlan and List 2007], and the design of fundraising schemes more broadly [Landry et al. 2006]. Much less attention has been given to why certain segments of society, such as aristocrats, give, although as Andreoni [2006] discusses, a body of non-experimental evidence has emerged on the non-linear relationship between household wealth and giving.

The second strand of literature to which we contribute studies why corporates give to charitable causes. Two main explanations have been proposed [Navarro 1988]. The first argues that managers choose the level of charitable donations that maximize the firm's profits, as this level of donations might be positive for a variety of reasons: (i) corporate donations may be used as a form of advertising or to enhance their reputation [Elfenbeim et al. 2010], thus stimulating demand for the firm's output ${ }^{5}$; (ii) donations improve the social environment in the local community and may reduce labor costs: workers may be willing to work for lower wages (or may be less inclined to shirk) if they live in an area that offers better recreational, cultural, health and sport facilities; (iii) in the long run, donations to educational/research institutions can increase the supply of qualified labor. If managers choose the profit-maximizing level of donations, they should set the marginal benefit of donations equal to their marginal cost. In the context of our field experiment, we should then expect corporate donations to be sensitive to variations in the price of giving, and potentially also sensitive to be presence of lead donors that might signal the quality of the charitable project [Vesterlund 2003].

An alternative explanation is that managers use corporate donations to maximize their own utility rather than the firm's profits. Corporate donations may give the manager private utility, either because of the warm glow from the donation act itself or because of the private benefits the manager may get from corporate donations. In our context, donations to the fundraising drive organized by the opera house might secure the manager good seats at the shows and invitations to dinners and parties attended by celebrity opera singers. Hence in the presence of such agency problems within the firm where managers are not donating their own money, we should expect relative to individual donations, corporate donations to be less sensitive to changes in the relative price of giving or the presence of lead donors.

Navarro [1988] and Boatsman and Gupta [1996] use changes in corporate tax rates in the US to

\footnotetext{
${ }^{5}$ This holds also if donations are anonymous, as the firm can still advertise how much money it donates to charity overall, thus improving its reputation as a socially responsible firm. This may increase the firm's sales among those customers that value (corporate) charitable giving.
} 
provide evidence on in tested between the two explanations of corporate giving behavior, although this evidence remains mixed. Werbel et al. [2002] and Brown et al. [2006] present evidence more in line with the existence of agency problems within firms so that managers choose charitable contributions to maximize their own utility rather than profitability. ${ }^{6}$

Our field experiment allows us to explore the sensitivity of corporate and aristocratic giving to the presence of lead donors, and the relative price of giving. In doing so we enter the debate on why corporates give by taking an innovative approach: rather than focusing on changes in corporate tax rates, we exploit experimental variation in the match rates and the presence of a lead donor within the same fundraising drive. The presence of a lead donor may be interpreted as a signal of good project quality, thus affecting the perceived marginal benefit of donations; at the same time, introducing different match rates creates variation in the price of giving. If corporate giving behavior is found to be sensitive to the presence of a lead donor or to match rates in the same manner as individual giving this is suggestive of managers not biasing corporate giving decisions for private benefits, but rather behaving more in line with choosing the profit-maximizing level of donations. On the other hand, if corporate donations do not react to these treatments, this is more indicative of agency problems within the firm, whereby managers use the firm's resources in the form of corporate donations, to gain purely private benefits.

Of course the primary challenge faced by any study of the behavior of such a specific type of donors - such as corporates or aristocrats - is that sample sizes are inevitably small and precise causal impacts hard to measure. This study is not exempt from these concerns. Throughout we try to be clear on what can be inferred from our findings and what needs further study. However overall our results indicate that the use of field experiments - that are now widely used to understand charitable giving more broadly - remain a useful tool to answer questions related to even a small fraction of potential donors such as corporates and aristocrats, especially when such donor types contribute disproportionately large amounts in aggregate, to charitable causes.

The remainder of this note is organized as follows. Section 2 describes the field experiment. Section 3 presents the main results on the intensive and extensive margins of charitable giving. Section 4 concludes with a broader discussion on the hurdles to be overcome for future studies that aim to shed light on the philanthropic behavior of corporates and elites.

\section{The Natural Field Experiment}

In June 2006 the Bavarian State Opera organized a mail out of 25,000 letters designed to elicit donations for a social youth project the opera was engaged in, "Stück für Stück". The mail out

\footnotetext{
${ }^{6} \mathrm{~A}$ related literature studies how corporate donors allocate their charitable expenditures across organizations. Leclair and Gordon [2000] present evidence that firms contribute more to charities that are more closely related to their own activities. Card et al. [2008] show that firms give more to charities based close to their headquarters, although this effect disappears once the number of wealthy individuals in the location is controlled for.
} 
recipients were randomly selected from the opera's database of customers who had purchased at least one ticket in the twelve months prior to the mail out. Recipients could correspond to corporates, aristocratically titled individuals such as Barons and Earls, or to non-titled individuals. Recipients were randomly assigned to one of four treatments that varied in two dimensions: (i) whether information was conveyed about the existence of an anonymous lead donor; (ii) how individual donations would be matched by the anonymous lead donor. The mail-out letters were identical in all treatments with the exception of one paragraph. The Appendix shows the format and wording of the mail out. The control treatment (T1) was such that recipients were provided no information about the existence of a lead donor, and offered no commitment to match individual donations. The wording of the key paragraph in the letter read as follows,

T1 (Control): This is why I would be glad if you were to support the project with your donation.

This paragraph is manipulated in the other treatments. In the second treatment (T2) recipients were informed that the project had already garnered a lead gift of $€ 60,000$. The corresponding paragraph read as follows,

T2 (Lead Donor): A generous donor who prefers not to be named has already been enlisted. He will support "Stück für Stück" with €60,000. Unfortunately, this is not enough to fund the project completely which is why I would be glad if you were to support the project with your donation.

The control and lead donor treatments differ only in that in the latter recipients are informed of the presence of a lead donor. There is no offer to match donations in any way in either treatment. Such substantial lead donations might affect the giving behavior of others because they eliminate an equilibrium in which all donations are zero [Andreoni 1998], they act as a signal of project quality [Vesterlund 2003], or because of a snob appeal effect that makes individual contributions increase in the contributions of others [Romano and Yildirim 2001]. These models provide less clear-cut predictions on how the various types of potential donors we study-individuals, aristocrats and corporates - might differentially react to such lead gifts. Our discussion above suggests that if corporates are found to be responsive to the presence of a lead donor, this is in line with managers choosing the profit-maximizing level of corporate donations.

The third class of treatments all provide recipients information on the existence of the lead donor but vary the relative price of giving in some way. To preserve adequate sample sizes in each donor type-treatment cell, we bundle together three different matching treatments. In the first, donations are matched by the anonymous lead donor at a $50 \%$ rate (so that giving one Euro would correspond to the opera receiving $€ 1.50$ ), in the second a $100 \%$ rate if offered, and in the third a $100 \%$ match rate is offered conditional on the donation being above $€ 50$. For the $50 \%$ match rate offer, the corresponding paragraph in the mail out letter read as follows, ${ }^{7}$

\footnotetext{
${ }^{7}$ The $100 \%$ match rate offer was analogously worded. The treatment where the $100 \%$ match was conditional on the donation being at least $€ 50$ was explained as follows: "A generous donor who prefers not to be named has already been enlisted. He will support "Stück für Stück" with up to €60,000 by donating, for each donation above $€ 50$ that we receive within the next four weeks, the same amount himself. In light of this unique opportunity I
} 
T3 (Matching): A generous donor who prefers not to be named has already been enlisted. He will support "Stück für Stück" with up to €60,000 by donating, for each Euro that we receive within the next four weeks, another 50 Euro cent. In light of this unique opportunity I would be glad if you were to support the project with your donation.

The final treatment (T4) offered recipients a fixed positive match of $€ 20$ for any positive donation. We refer to this as the 'income' treatment because conditional on making any positive donation it is as if the donor receives a lump sum transfer of $€ 20$. This treatment was explained in the mail out letter as follows,

T4 (Income): A generous donor who prefers not to be named has already been enlisted. He will support "Stück für Stück" with up to €60,000 by donating, for each donation that we receive within the next four weeks regardless of the donation amount, another $€ 20$. In light of this unique opportunity I would be glad if you were to support the project with your donation.

This treatment allows us to bound the share of each recipient type for whom, the marginal utility of even contributing a small amount is close to zero and are therefore unlikely to donate under any realistic circumstances given any small transactions costs of donating.

As discussed in Huck and Rasul [2010], four further points are of note. First, the opera had no fundraising target in mind, nor was any target discussed in the mail out. Funds raised for the project were used to finance a series of small events, as made clear in the mail out letter. Hence recipients know that marginal contributions will make a difference. Second, recipients were told the matching schemes would be in place for four weeks, with over $95 \%$ recipients that donated, doing so in this time frame. Third, recipients are told the truth - the lead gift was actually provided and each matching scheme was implemented. The value of matches was capped at $€ 60,000$ which ensured recipients were told the truth even if the campaign was more successful than anticipated. Finally, the project's beneficiaries are children from disadvantaged families whose parents are almost surely not among the recipients of the mail out. Hence the fundraising campaign relates to a project that conveys no immediate benefits to potential donors, ensuring there is no role for gift exchange or reciprocity in driving donations, as in Falk [2007]. As donors are not publicly announced, there is no role for social recognition to drive behavior, that might plausibly differ across the types of donor considered.

\section{Results}

\subsection{Recipient Characteristics}

The original mail out was sent to 25,000 recipients on the opera house's customer database. After removing missing values and extreme outliers, our working sample is based on mail-outs sent to would be glad if you were to support the project with your donation." 
22,318 individual recipients, 362 corporates and 53 aristocrats, as shown in Column 1 of Table 2. ${ }^{8}$ Aristocratic recipients are so called because each has a formal title of some sort. Our sample includes recipients with the following titles: Baron/Baronin (Freiherr/Freifrau), and Graf/Gräfinwhich is a historical German noble title similar in rank to a count or a British earl. In the German context, we might expect such elites to have long philanthropic associations with arts and culture. ${ }^{9}$

The remaining columns provide information on recipients' opera attendance. ${ }^{10}$ Individual recipients purchase around six tickets in the year prior to the mail out in two separate orders. The average price per ticket is around $€ 87$ with the annual total spent on attendance averaging $€ 410$. Clearly, these individuals are not representative of the population. Our analysis therefore sheds light on how the behavior of elites and corporates differs from such selected individuals. To the extent that other organizations target charitable projects towards those with high affinity to the organization as well as those who are likely to have high income, the results have external validity in other settings.

Comparing individual and corporate recipients, Table 2 reveals that: (i) corporates purchase significantly more tickets, although place the same number of orders over the year prior to the mail-out; (ii) corporates spend significantly more per ticket. As a result, corporates spend almost five times as much on opera tickets as do individuals. Comparing individuals and aristocrats, Table 2 reveals there are no observable differences between the two. While aristocrats spend an average of $€ 10$ more per ticket than individuals, this is not a significant difference. Hence at least in terms of these proxies of affinity to the opera, aristocratic recipients do not much differ from individual recipients.

\subsection{Who Donates?}

Table 3 provides evidence on the observable characteristics of donors and non-donors for each recipient type. We report the mean and standard error of each characteristic, as well as the $p$ value on the null hypothesis that the characteristic is the same among donors and non-donors of the same recipient type. As documented in Huck et al. [2013], the response rate, averaged across treatments is $4.1 \%$ among individual recipients. Comparing individual donors and non-donors, donors purchase significantly more tickets in the year prior to the mail out, place more separate orders over the same time period, and are significantly more likely to have last attended the opera recently. In contrast, the average price per ticket does not differ significantly between individual donors and non-donors. These results suggest that affinity to the opera house - as measured by

\footnotetext{
${ }^{8}$ We had to exclude some observations due to missing values in the variables used anywhere in the analysis. We also exclude non-Germans, and individual recipients for which no gender can be assigned. Additionally, we excluded a small number of observations that were extreme outliers in terms of donations given, defined as those that gave more than four standard deviations more than the mean in the same treatment-recipient type cell.

${ }^{9}$ On corporates we cannot reveal further information except that $45 \%$ are registered in Munich zip codes. In comparison, $46 \%$ (49\%) of individual (titled) recipients reside in Munich.

${ }^{10}$ Given random assignment, there are insignificant differences on observables across treatments by recipient type.
} 
the number of ticket purchases, separate ticket orders, and time of last attendance - is strongly correlated to the behavior of individuals along the extensive margin of whether to donate or not. In contrast, characteristics that more closely proxy individual income are less correlated with whether the individual responds to the mail out.

Comparing across recipient types, we see that although corporates and individuals have similar response rates to each other, a remarkable $13 \%$ of aristocratic recipients donate to the fundraising project. We know of no other study - even highly targeted campaigns - in which such high response rates to a charitable fundraising drive have been generated. For corporates, there are no significant differences on observables between donors and non-donors, except that donors order more tickets than non-donors. Similarly for aristocratic recipients, on observables there are no significant differences between aristocratic donors and non-donors, except that donors are significantly more likely to have purchased a ticket recently. Hence, from the perspective of the charitable organization, the results show that it is relatively easy to predict which individuals are most likely to respond to fundraising drives - namely those with more affinity to the opera house. However, making similar predictions among corporates and aristocrats is harder, because unobservables largely drive behavior on the extensive margin of giving.

\subsection{Giving Behavior}

Table 4 provides evidence on donations given and received by recipient type and treatment. The donation given relates to amount donated by the donor, and the donation received includes the value of the match, that is relevant for treatments T3 and T4. Given the small number of aristocrats that donate in the sample, we avoid making any claims about the giving behavior of such recipients beyond what has already been noted on the extensive margin of giving. This is an inevitable drawback of trying to study the behavior of a small, albeit important, group of potential donors. Hence in Table 4 we focus the discussion on comparing individual to corporate donors.

We see that response rates do not significantly differ between treatments $\mathrm{T} 1$ and $\mathrm{T} 2$ while there is a significant increase from T2 to T3 (which, however, disappears when T2 is compared to the different types of matching schemes aggregated here in T3, see Huck and Rasul [2010] for details). Comparing individual response rates between $\mathrm{T} 2$ and $\mathrm{T} 4$, we see that a pure income transfer in T4 induces significantly more individuals to give, as expected.

Column 3 shows that in the control treatment T1, the average donation given by individuals is $€ 74.2$. In the lead donor treatment $\mathrm{T} 2$, this rises significantly to $€ 133$. The near doubling of donations given can only be a response to the presence of a lead donor. Combining this with the previous result on response rates, we note that while such lead donors do not induce new individual donors to enter, recipients who like the project to begin with like it even more when they observe that somebody else is already strongly committed to it.

As the relative price of donations received falls moving from treatment T2 to the linear match- 
ing treatments in T3, the average donation received from individuals (including the match) rises from $€ 133$ to $€ 174$. As the match rate increases, donations given by individuals fall indicating some crowding out. Comparing outcomes from the income matching scheme T4 to the lead donor treatment T2, we see that average donations given fall from $€ 133$ to $€ 67.9$. Combining this with the previous result that response rates significantly rise moving from T2 to T4, it becomes apparent that the additional individuals that are induced in T4 relative to T2 are those with low willingness to pay. This issue is explored further in Huck et al. [2015] that focuses exclusively on the behavior of individual recipients.

Comparing donations across treatments, we find significant differences in the donations given. Hence we can rule out that individual preferences can be characterized by pure warm glow so they only care about the donation given rather than that actually received, irrespective of the match rate faced. Similarly we find significant differences across treatments in the amounts received by the project, including the match. Hence we can also rule out that individual recipients are engaged in pure donation targeting, where individuals choose to give an amount so that the project always receives the same amount, irrespective of the match rate. In terms of effectiveness, Columns 5 and 6 show the return per mailed letter which highlights again the superiority of the treatment with a lead donor who makes an unconditional contribution (T2). Of course, if the lead donor insists on matching, this still beats the baseline without any kind of lead gift.

Comparing across recipient types, we do not find systematic differences in the extensive margins between individual and corporate donors. Column 2 shows that response rates among corporate recipients do not significantly vary with the exception of a borderline significant fall in reaction to proportional matching (comparing T2 to T3).

Turning to the intensive margins for corporate donors in Columns 7, 8, 9, and 10, we first note that they give significantly more than individuals in all treatments. While perhaps unsurprising, it is still an important result for practical purposes. Corporate donors should receive extra attention from fundraisers if they can be identified as such. Comparing the giving behavior of corporate donors in T2 and T3, Columns 7 and 8 show that corporates, too, reduce their average donations once matching kicks in. However, contrary to individuals this reduction is at best borderline significant (for a one-tailed version of the reported test). Comparing corporate behavior in $\mathrm{T} 2$ to T4 we find for corporate donors display much less of a reaction to pure income transfers.

In terms of effectiveness, our two borderline significant findings for corporates (a lower response rate and smaller donations given in response to proportional matching) reinforce each other and render T2 with an expected donation of $€ 11.70$ vastly more effective per letter sent than T3 which has a meagerly expected donation of $€ 2.05 .^{11}$

\footnotetext{
${ }^{11}$ We refrain from comparisons with the control treatment as there is just one very large donation there.
} 


\section{Conclusions}

This note takes some tentative steps to shed light on the charitable giving behavior of two types of donor that are not much studied but provide disproportionately large amounts to charity in aggregate: aristocrats and corporates. We present evidence from a natural field experiment that allows us to compare their response to a charitable fundraising project to that of individual donors. Our analysis of corporate giving is distinguished from previous work that exploits changes in income or tax rates [Clotfelter 1985, Navarro 1988, Boatsman and Gupta 1996], or that measures how corporate giving is correlated to firm characteristics [Brown et al. 2006]. Similarly, our analysis of giving by elites is distinguished from previous work that has largely been based on data from tax filings of the very wealthy [Andreoni 2006].

Our field experiment sheds light on how the giving behavior of corporates and aristocrats responds to the presence of large lead donors, and the relative price of giving. We find that aristocratic donors are significantly more responsive to the same charitable drive than other donor types and that corporates give significantly larger amounts. Both, are precious for the fundraiser.

Regarding corporate response to the presence of a lead donor and to matching our results are ambiguous. While point estimates indicate that corporate donations are similarly price elastic as individual ones the resulting crowding out is only borderline significant. However, coupled with a reduction in the response rate which also borders on significance we find that proportional matching vastly reduces the effectiveness of the fundraising drive for corporates.

While adverse effects of matching are also present for individuals and have been documented before in Huck and Rasul [2010] and Huck et al. [2015] the effect we observe for corporates is even more dramatic and suggests that, even if fundraisers might be forced by competition or indeed their lead donors to rely on proportional matching schemes, they may want to target corporates separately. Corporate donors are a valuable source for the fundraiser and may require (and deserve) special treatment.

Moving forward, an Achilles heel for this type of research question will remain the relatively small number of corporate and aristocratic donors to any charitable organization, even if these types of donors contribute a relatively large share of all donations received. For example, since the Bavarian State Opera started "small money" fundraising through unsolicited letters in 2006 they have raised a little over half a million Euros through such drives. On the other hand, they earn about 3 million euros per year through large donations from corporates and wealthy donors. Hence although we see a role for research designs based on experimental methods to establish causal determinants of giving of different types of potential donor, we envisage future work might also encompass the use of qualitative interviews with these types of scarce donor, for example. Here we focus on aristocrats and corporates as we can identify these two groups from the data we have. More generally, one might want to study wealthy donors and those that have traditions of philanthropic activities such as large parts of, say, the "East coast aristocracy", wealthy "old- 
money" families who have engaged in giving for generations. To that extent, our research into titled donors also has relevance for countries that have abolished formal aristocratic titles.

Despite the obvious challenges, given the growth in wealth (and giving) of corporates and the very wealthy, an agenda to explore their motives and decision rules remains worth pursuing, both, from the fundraiser's as well as from the economist's point of view.

\section{References}

[1] Andreoni.J (1998) "Toward a Theory of Charitable Fund-Raising", Journal of Political Economy 106: 1186-213.

[2] Andreoni.J (2006) "Philanthropy", in The Handbook on the Economics of Giving, Reciprocity and Altruism, S.C.Kolm and J.Mercier Ythier (eds.), Amsterdam: North Holland.

[3] Auten.G.e, H.Sieg, And C.t.clotfelter (2002) "Charitable Giving, Income, and Taxes: An Analysis of Panel Data", American Economic Review 92: 371-82.

[4] Bottsman.J.R And S.gupta (1996) "Taxes and Corporate Charity: Empirical Evidence from Microlevel Panel Data", National Tax Journal 49: 193-213.

[5] BRown.W.o, E.Helland And J.K.SMith (2006) "Corporate Philanthropic Practices", Journal of Corporate Finance 12: 855-77.

[6] CARD.D, K.F.HAllock And E.moretti (2010) "The Geography of Giving: The Effect of Corporate Headquarters on Local Charities", Journal of Public Economics 94: 222-34.

[7] Clotfelter.c.t (1985) Federal Tax Policy and Charitable Giving, Chicago: University of Chicago Press.

[8] Elfenbein.D.w And B.mCmanus (2010) "A Greater Price for a Greater Good? Evidence that Consumers Pay More for Charity-Linked Products", American Economic Journal: Economic Policy 2: 28-60.

[9] FALK.A (2007) "Gift-Exchange in the Field", Econometrica 75: 1501-11.

[10] HUCK.S, I.RASUl AND A.SHEPhARD (2015) "Comparing Charitable Fundraising Schemes: Evidence from a Natural Field Experiment and a Structural Model", forthcoming, American Economic Journal: Economic Policy.

[11] HUCK.S AND I.RASUl (2011) "Matched Fundraising: Evidence from a Natural Field Experiment", Journal of Public Economics 95: 351-62. 
[12] Karlan.D AND J.A.List (2007) "Does Price Matter in Charitable Giving? Evidence from a Large-Scale Natural Field Experiment", American Economic Review 97: 1774-93.

[13] LANDRY.C.E, A.LANGE, J.A.LIST, M.K.PRICE AND N.G.RUPP (2006) "Toward an Understanding of the Economics of Charity: Evidence from a Field Experiment", Quarterly Journal of Economics 121: 747-82.

[14] LECLAIR.M.S. AND K.GORDON (2000) "Corporate Support for Artistic and Cultural Activities: What Determines the Distribution of Corporate Giving?", Journal of Cultural Economics 24: 225-41.

[15] Navarro.P (1998) "Why Do Corporations Give to Charity?", Journal of Business 61: 65-93.

[16] Randolph.W.C (1995) "Dynamic Income, Progressive Taxes, and the Timing of Charitable Contributions", Journal of Political Economy 103: 709-38.

[17] Romano.R And H.Yildirim (2001) "Why Charities Announce Donations: A Positive Perspective", Journal of Public Economics 81: 423-47.

[18] Vesterlund.L (2003) "The Informational Value of Sequential Fundraising", Journal of Public Economics 87: 627-57.

[19] Werbel.J.D AND S.M.CARTER (2002) "The CEO's Influence on Corporate Foundation Giving", Journal of Business Ethics 40: 47-60. 
Table 1: Donations by Source and Charitable Sector (Means)

\begin{tabular}{|c|c|c|c|c|c|c|}
\hline Charitable Sector & $\begin{array}{l}\text { Overall Donations } \\
\qquad(1) \\
\end{array}$ & $\begin{array}{c}\text { Government/Not for profit } \\
\text { Donations } \\
(2) \\
\end{array}$ & $\begin{array}{c}\text { Corporate } \\
\text { Donations } \\
\text { (3) } \\
\end{array}$ & $\begin{array}{l}\text { Individual Donations } \\
\text { (4) }\end{array}$ & $\begin{array}{c}\text { Corporate/Overall } \\
(5) \\
\end{array}$ & $\begin{array}{c}\text { Individual/Corporate } \\
\text { (6) } \\
\end{array}$ \\
\hline Humanitarian Relief & $381,167,308$ & $104,957,685$ & $114,321,942$ & $138,399,361$ & 0.30 & 1.21 \\
\hline Medical & $241,932,317$ & $24,942,827$ & $107,157,673$ & $75,325,302$ & 0.44 & 0.70 \\
\hline Environment & $121,666,794$ & $17,274,692$ & $15,171,786$ & $62,369,851$ & 0.12 & 4.11 \\
\hline Arts and Culture & $54,131,539$ & $2,341,136$ & $10,658,940$ & $36,638,668$ & 0.20 & 3.44 \\
\hline Education & $169,352,981$ & $103,188,576$ & $17,775,340$ & $11,628,994$ & 0.10 & 0.65 \\
\hline All Charitable Sectors & $229,982,731$ & $56,890,350$ & $67,852,553$ & $78,233,320$ & 0.30 & 1.15 \\
\hline
\end{tabular}

Notes: All monetary amounts are measured in US dollars. Data is collected for 199 of the 200 charities listed in Forbes' 2005 "American 200 Largest Charities" list. The charity "World Opportunitites" was excluded from the analysis as information on the charity is not accessible online. The most recent publicly accessible annual reports and balance sheets were examined for each of the 199 charities included in the analysis. It was possible to recover detailed information on the sources of funds for 20 of the 199 charities. For all 20 charities it was possible to separately identify the amounts coming from individuals and governments. For 16 of the 20 charities it was possible to identify the amount coming from corporations. For 4 of the 20 charities the amount falling under "corporate donations" includes the sum of corporate donations and donations from foundations (the balance sheets of those 4 charities do not allow to separate the two sources). The analysis presented in Table 1 is based on the subsample composed by these 20 charities. The sum of the entries in columns (2) to (4) is less than the corresponding entry in column (1) due to the presence of other donation sources, such as foundations. The following assumptions were made regarding donation sources: (i) donations falling under the heading "Legacies" or "Bequests" are assumed to come from individuals; (ii) amounts falling under the heading "Gifts In-Kind" or "Donated Services" are equally split between individuals and corporations, unless it is clearly stated in the financial statements what their origin is. The classification of the 20 charities in the five areas reported above is based on the type of core activities performed by the charity. The Humanitarian Relief group includes the following charities: Carter Center, Catholic Relief Services, Feeding America, Heifer Intl., Marine Toys for Tots Foundation, Unicef USA. The Medical group includes the following charities: Arthritis Foundation, Brother's Brother, Children's Hospital of Philadelphia, PATH, Project Hope. The Environment group includes the following charities: Conservation International Foundation, National Wildlife Federation, Natural Resources Defence Council, World Wide Fund. The Arts and Culture group includes the following charities: San Francisco Opera Association, WETA. Charities in the Education

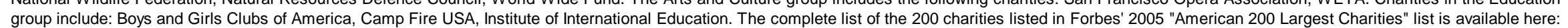
http://www.forbes.com/2005/11/18/largest-charities-ratings_05charities land.html. 
Table 2: Characteristics of Recipient Types

Mean, standard error in parentheses

P-value on test of equality of means with control group in brackets

\begin{tabular}{|c|c|c|c|c|c|c|}
\hline Recipient Type & $\begin{array}{c}\text { Number of } \\
\text { Individuals } \\
\text { (1) }\end{array}$ & $\begin{array}{l}\text { Number of Tickets } \\
\text { Bought in Last } 12 \\
\text { Months } \\
\text { (2) }\end{array}$ & $\begin{array}{l}\text { Number of Ticket } \\
\text { Orders in Last } 12 \\
\text { Months } \\
\text { (3) }\end{array}$ & $\begin{array}{l}\text { Average Price of } \\
\text { Tickets Bought in } \\
\text { Last } 12 \text { Months } \\
\text { (4) }\end{array}$ & $\begin{array}{l}\text { Total Value of All } \\
\text { Tickets Bought in } \\
\text { Last } 12 \text { Months } \\
\text { (5) }\end{array}$ & $\begin{array}{c}\text { Year of Last Ticket } \\
\text { Purchase }[2006=1] \\
\text { (6) }\end{array}$ \\
\hline Individuals (control group) & 22318 & $\begin{array}{c}5.86 \\
(.051)\end{array}$ & $\begin{array}{c}2.04 \\
(.013)\end{array}$ & $\begin{array}{c}86.7 \\
(.268)\end{array}$ & $\begin{array}{c}410 \\
(2.93)\end{array}$ & $\begin{array}{c}.565 \\
(.003)\end{array}$ \\
\hline Corporates & 362 & $\begin{array}{l}18.27 \\
(1.70)\end{array}$ & $\begin{array}{c}1.99 \\
(.115)\end{array}$ & $\begin{array}{c}112 \\
(2.40)\end{array}$ & $\begin{array}{l}1878 \\
(177)\end{array}$ & $\begin{array}{c}.583 \\
(.026)\end{array}$ \\
\hline Test of Equality With Control Group [p-value] & & {$[.000]$} & [.697] & {$[.000]$} & {$[.000]$} & {$[.504]$} \\
\hline Titled & 53 & $\begin{array}{c}5.15 \\
(.670)\end{array}$ & $\begin{array}{c}1.79 \\
(.241)\end{array}$ & $\begin{array}{c}97.1 \\
(7.48)\end{array}$ & $\begin{array}{c}389 \\
(43.3)\end{array}$ & $\begin{array}{c}.642 \\
(.066)\end{array}$ \\
\hline Test of Equality With Control Group [p-value] & & {$[.291]$} & {$[.311]$} & {$[.164]$} & {$[.633]$} & {$[.249]$} \\
\hline
\end{tabular}

Notes: All figures refer to the mail out recipients in each treatment. The tests of equality are based on an OLS regression allowing for robust standard errors. All monetary amounts are measured in Euros. In Columns 2 to 5

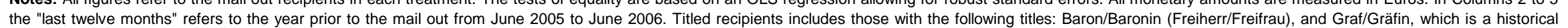
German noble title similar in rank to a count or a British earl. 
Table 3: Characteristics of Donors and Non Donors by Recipient Type

Mean, standard error in parentheses

P-value on test of equality of means with comparison group in brackets

\begin{tabular}{|c|c|c|c|c|c|c|c|}
\hline Recipient Type & $\begin{array}{c}\text { Number of } \\
\text { Responses } \\
\text { (1) }\end{array}$ & $\begin{array}{l}\text { Response } \\
\text { Rate } \\
\text { (2) }\end{array}$ & $\begin{array}{l}\text { Number of Tickets } \\
\text { Bought in Last } 12 \\
\text { Months } \\
\text { (3) }\end{array}$ & $\begin{array}{l}\text { Number of } \\
\text { Ticket Orders in } \\
\text { Last } 12 \text { Months } \\
\text { (4) }\end{array}$ & $\begin{array}{l}\text { Average Price of } \\
\text { Tickets Bought in } \\
\text { Last } 12 \text { Months } \\
\text { (5) }\end{array}$ & $\begin{array}{l}\text { Total Value of All } \\
\text { Tickets Bought in } \\
\text { Last } 12 \text { Months } \\
\text { (6) }\end{array}$ & $\begin{array}{l}\text { Year of Last Ticket } \\
\text { Purchase }[2006=1] \\
\text { (7) }\end{array}$ \\
\hline \multirow[t]{2}{*}{ Individual Donors } & 909 & .041 & 8.11 & 2.67 & 87.6 & 621 & .697 \\
\hline & & $(.001)$ & $(.301)$ & $(.080)$ & $(1.40)$ & (24.3) & $(.016)$ \\
\hline \multirow[t]{2}{*}{ Individual Non Donors } & & & 5.76 & 2.01 & 86.6 & 401 & .560 \\
\hline & & & $(.052)$ & $(.013)$ & $(.274)$ & $(2.86)$ & $(.003)$ \\
\hline \multicolumn{2}{|l|}{ Donors equal to non donors [p-value] } & & {$[.000]$} & {$[.000]$} & {$[.468]$} & {$[.000]$} & {$[.000]$} \\
\hline \multirow[t]{2}{*}{ Corporate Donors } & 12 & .033 & 8.92 & 2.83 & 118 & 986 & .75 \\
\hline & & $(.009)$ & (2.63) & $(1.01)$ & $(12.9)$ & $(277)$ & $(.128)$ \\
\hline \multirow[t]{2}{*}{ Corporate Non Donors } & & & 18.59 & 1.96 & 112 & 1909 & .577 \\
\hline & & & $(1.76)$ & $(.113)$ & $(2.43)$ & $(184)$ & $(.026)$ \\
\hline \multicolumn{2}{|l|}{ Donors equal to non donors [p-value] } & & {$[.687]$} & {$[.070]$} & {$[.675]$} & {$[.580]$} & {$[.233]$} \\
\hline \multirow[t]{2}{*}{ Titled Donors } & 7 & .132 & 4.14 & 1.86 & 88.2 & 296 & 1 \\
\hline & & $(.047)$ & $(1.27)$ & $(.424)$ & $(16.4)$ & $(58.9)$ & $(.074)$ \\
\hline \multirow[t]{2}{*}{ Titled Non Donors } & & & 5.30 & 1.78 & 98.41 & 404 & .587 \\
\hline & & & $(.766)$ & $(.278)$ & $(8.50)$ & $(50.2)$ & $(.074)$ \\
\hline \multicolumn{2}{|l|}{ Donors equal to non donors [p-value] } & & {$[.967]$} & {$[.200]$} & {$[.833]$} & {$[.833]$} & {$[.036]$} \\
\hline
\end{tabular}

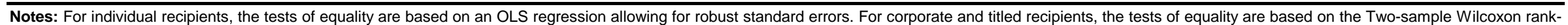

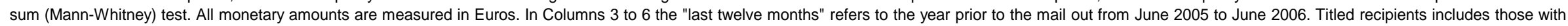
the following titles: Baron/Baronin (Freiherr/Freifrau), and Graf/Gräfin, which is a historical German noble title similar in rank to a count or a British earl. 


\section{Table 4: Outcomes by Treatment and Recipient Type}

\section{Mean, standard error in parentheses}

$P$-values on tests of equality of means with comparison group in brackets

\begin{tabular}{|c|c|c|c|c|c|c|c|c|c|c|c|c|}
\hline \multirow{3}{*}{$\begin{array}{l}\text { Treatmen } \\
\text { t Number }\end{array}$} & \multirow{3}{*}{ Treatment Description } & \multirow{3}{*}{$\begin{array}{c}\text { Comparison } \\
\text { Group }\end{array}$} & \multicolumn{2}{|c|}{ Response Rates } & \multicolumn{4}{|c|}{ Individuals } & \multicolumn{4}{|c|}{ Corporates } \\
\hline & & & \multicolumn{2}{|c|}{ Individuals Corporates } & \multirow{2}{*}{$\begin{array}{c}\text { Donation } \\
\text { Given } \\
(3)\end{array}$} & \multirow{2}{*}{$\begin{array}{c}\text { Donation } \\
\text { Received } \\
\text { (4) }\end{array}$} & \multirow{2}{*}{$\begin{array}{c}\text { Expected } \\
\text { Donation } \\
\text { Given per } \\
\text { Letter } \\
\text { (5) }\end{array}$} & \multirow{2}{*}{$\begin{array}{l}\text { Expected } \\
\text { Donation } \\
\text { Received per } \\
\text { Letter } \\
\text { (6) }\end{array}$} & \multirow{2}{*}{$\begin{array}{c}\begin{array}{c}\text { Donation } \\
\text { Given }\end{array} \\
(7)\end{array}$} & \multirow{2}{*}{$\begin{array}{c}\text { Donation } \\
\text { Received } \\
\text { (8) }\end{array}$} & \multirow{2}{*}{$\begin{array}{l}\text { Expected } \\
\text { Donation Given } \\
\text { per Letter } \\
\text { (9) }\end{array}$} & \multirow{2}{*}{$\begin{array}{l}\text { Expected Donation } \\
\text { Received per Lette } \\
\text { (10) }\end{array}$} \\
\hline & & & (1) & (2) & & & & & & & & \\
\hline T1 & Control & & .037 & .022 & 74.2 & 74.2 & 2.77 & 2.77 & 1000 & 1000 & 21.7 & 21.7 \\
\hline & & & $(.003)$ & $(.022)$ & $(6.27)$ & $(6.27)$ & & & $(\mathrm{N} / \mathrm{A})$ & $(\mathrm{N} / \mathrm{A})$ & & \\
\hline \multirow[t]{3}{*}{ T2 } & Lead donor & & .035 & .064 & 133 & 133 & 4.61 & 4.61 & 183 & 183 & 11.7 & 11.7 \\
\hline & & & $(.003)$ & $(.036)$ & (14.6) & (14.6) & & & $(44.1)$ & $(44.1)$ & & \\
\hline & & T1 Control & [.519] & [.320] & {$[.000]$} & {$[.000]$} & & & [.180] & [.180] & & \\
\hline \multirow[t]{4}{*}{ T3 } & Lead donor + proportional & & .042 & .020 & 95.4 & 174 & 4.00 & 7.28 & 103 & 161 & 2.05 & 3.23 \\
\hline & matching & & $(.002)$ & $(.010)$ & $(6.04)$ & (10.8) & & & (34.2) & (48.8) & & \\
\hline & & T1 Control & [.199] & [.940] & {$[.015]$} & {$[.000]$} & & & {$[.157]$} & [.157] & & \\
\hline & & T2 Lead donor & {$[.036]$} & [.104] & {$[.016]$} & {$[.027]$} & & & {$[.150]$} & {$[.724]$} & & \\
\hline \multirow[t]{4}{*}{ T4 } & Lead donor +20 Euros & & .047 & .058 & 67.9 & 87.9 & 3.18 & 4.11 & 125 & 145 & 7.25 & 8.41 \\
\hline & match for any donation & & $(.003)$ & $(.028)$ & $(5.47)$ & $(5.47)$ & & & $(25)$ & (25) & & \\
\hline & & T1 Control & {$[.040]$} & {$[.353]$} & {$[.446]$} & {$[.102]$} & & & {$[.114]$} & [.114] & & \\
\hline & & T2 Lead donor & {$[.007]$} & {$[.897]$} & {$[.000]$} & {$[.004]$} & & & {$[.237]$} & {$[.714]$} & & \\
\hline
\end{tabular}

Notes: For individuals, the tests of equality are based on an OLS regression allowing for robust standard errors. For corporates, the tests of equality are based on the Two-sample Wilcoxon rank-sum (Mann-Whitney) test. All monetary amounts are measured in

Euros. 


\section{Appendix: The Mail Out Letter (Translated)}

Bayerische Staatsoper

Staatsintendant

Max-Joseph-Platz 2, D-80539 München

www.staatsoper.de

\section{[ADDRESS OF RECIPIENT]}

\section{Dear [RECIPIENT],}

The Bavarian State Opera House has been investing in the musical education of children and youths for several years now as the operatic the art form is in increasing danger of disappearing from the cultural memory of future generations.

Enthusiasm for music and opera is awakened in many different ways in our children and youth programme, "Erlebnis Oper" [Experience Opera]. In the forthcoming season 2006/7 we will enlarge the scope of this programme through a new project "Stück für Stück" that specifically invites children from schools in socially disadvantaged areas to a playful introduction into the world of opera. Since we have extremely limited own funds for this project, the school children will only be able to experience the value of opera with the help of private donations.

[This paragraph describes each matching scheme and is experimentally varied as described in the main text of the paper].

As a thank you we will give away a pair of opera tickets for Engelbert Humperdinck's "Konigskinder" on Wednesday, 12 July 2006 in the music director's box as well as fifty CDs signed by Maestro Zubin Mehta among all donors.

You can find all further information in the enclosed material. In case of any questions please give our Development team a ring on [phone number]. I would be very pleased if we could enable the project "Stück für Stück" through this appeal and, thus, make sure that the operatic experience is preserved for younger generations.

With many thanks for your support and best wishes,

Sir Peter Jonas, Staatsintendant 


\section{Appendix: The Mail Out Letter (Translated)}

\section{“Stück für Stück”}

The project "Stück für Stück" has been developed specifically for school children from socially disadvantaged areas. Musical education serves many different functions in particular for children and youths with difficult backgrounds -- it strengthens social competence and own personality, improves children's willingness to perform, and reduces social inequality. Since music education plays a lesser and lesser role in home and school education, the Bavarian State Opera has taken it on to contribute to it ourselves. The world of opera as a place of fascination is made attainable and accessible for young people.

In drama and music workshops, "Stück für Stück” will give insights into the world of opera for groups of around 30 children. They will be intensively and creatively prepared for a subsequent visit of an opera performance. These workshops encourage sensual perception - through ear and eye but also through scenic and physical play and intellectual comprehension - all of these are important elements for the workshops. How does Orpheus in "Orphee and Eurydice" manage to persuade the gods to let him save his wife from the realm of dead? Why does he fail? Why poses the opera "Cosi fan tutte" that girls can never be faithful? It is questions like these that are investigated on the workshops.

The workshops are also made special through the large number and variety of people who are involved in them: musicians, singers, directors, and people from many other departments, ranging from costumes and makeup to marketing. The participants in each workshop work through an opera's storyline, and are introduced to the production and will meet singers in their costumes as well as musicians. This makes the workshops authentic. After the workshops the participants are invited to see the actual opera production.

Through your donation the project "Stück für Stück" will be made financially viable so that we can charge only a small symbolic fee to the participants. This makes it possible to offer our children and youth programme also to children from socially disadvantaged backgrounds that can, thus, learn about the fascination of opera.

Note: In German, Stück für Stück is a wordplay --- "Stück” meaning "play" as in drama and "Stück für Stück" being an expression for doing something bit by bit. 